\title{
Estimation of age at death: examination of variation in cortical bone histology within the human clavicle
}

\author{
J. Sobol' ${ }^{1}$, I. Ptaszyńska-Sarosiek ${ }^{2}$, A. Charuta ${ }^{3}$, M. Oklota-Horba², Cz. Żaba ${ }^{1}$, \\ A. Niemcunowicz-Janica² \\ ${ }^{1}$ Department of Forensic Medicine, Medical University of Poznan, Poznan, Poland \\ ${ }^{2}$ Department of Forensic Medicine, Medical University of Bialystok, Bialystok, Poland \\ ${ }^{3}$ Vertebrates Morphology Department, Department of Zoology, Institute of Biology, Faculty of Natural Sciences, \\ Siedlce University of Natural Science and Humanities, Siedlce, Poland
}

[Received 30 July 2014; Accepted 1 December 2014]

\begin{abstract}
Background: Continuously, numerous human remains of unknown identity are revealed all over the world. One of the elements of the identification process may be a proper assessment of a histological section of bone fragments in order to answer questions related to the age of the subject. The aim of the study was to define an optimum bone fragment to obtain samples for histological examination.

Materials and methods: The study material consisted of fragments of shafts of left clavicles taken from 39 males and 25 females (aged 22-86). The clavicles came from autopsies conducted between 2005 and 2011 at the Department of Forensic Medicine of Poznan and the Bialystok Medical University. The following were taken into account while estimating the age of the bone remains: clavicle length (CL), clavicle width (CW), clavicle thickness (CT), number of osteons in the field of vision (ON), number of osteons with the Haversian canal of more than $70 \mu \mathrm{m}$ ( $\mathrm{HC}$ $>70 \mu \mathrm{m})$, average diameter of the Haversian canals (avg. $\varnothing \mathrm{HC}$ ), area occupied by interstitial lamellae (ILA \%), area occupied by osteons (OA \%), area occupied by fragments-remnants of osteons remain as irregular arcs of lamellar fragments (OFA \%), average thickness of outer circumferential lamellae (avg. OCL, $\mu \mathrm{m}$ ), the relation of osteons with the Haversian canal of more than $70 \mu \mathrm{m}$ in diameter to the total number of osteons (HC $>70 \mu \mathrm{m}, \%)$, at $p<0.00001$. The age of the bone remains was estimated using univariate linear regression function.

Results: It was determined that the best place for sampling the osseous tissue for the analysis was the shaft of the clavicle. It was stated than the number of osteons with a large diameter increased with age. The relation of osteons with the Haversian canal of more than $70 \mu \mathrm{m}$ in diameter to the total number of osteons (HC > $70 \mu \mathrm{m}, \%$ ). The level of statistical significant was $p<0.00001$. All analysed microscopic features of the osseous tissue showed significant statistical changes occurring with age.

Conclusions: The exact method for preparing osseous tissue for a microscopic analysis to determine the age of the remains is the preparation of histological sections, as the structure of the osseous tissue does not change while processing the material and the time of preparations is relatively short (7-8 days). The best predictors of age with the use of the function of univariate linear regression were: the diameter of Haversian canal, the number of osteons with Haversian canal of more than $70 \mu \mathrm{m}$ in diameter, the relation of osteons with Haversian canal bigger than $70 \mu \mathrm{m}$ in diameter to the total number of osteons as well as fragments of secondary osteons. (Folia Morphol 2015; 73, 3: 378-388)
\end{abstract}

Key words: human remains, age estimation, clavicle, bone histology, ground sections

Address for correspondence: A. Charuta, PhD, Vertebrates Morphology Department, Department of Zoology, Institute of Biology, Faculty of Natural Science, Siedlce University of Natural Sciences and Humanities, ul. Konarskiego 2, 08-110 Siedlce, Poland, tel: +48 256431286 , fax: +48 2564319 17, e-mail: anna.charuta@neostrada.pl, anna.charuta@uph.edu.pl 


\section{INTRODUCTION}

Identification of human bone remains has a long tradition both in forensic medicine and in physical anthropology. The process of identification begins with a formulation of a biological profile and the estimation of sex, age, ethnic origin and posture. It is known that variability of morphological features applied to estimate age of human skeleton increases with age. Thus, there are many research methods used for age at death estimation.

The choice of a technique and the way of identification of the remains is intrinsically connected with age. Franklin [6] suggested a research method based on the development of morphological features and their degeneration at an older age. This review, therefore, considers methods appropriate for age estimation in both young and adult remains; the former being primarily based on developmental morphological features and the latter on degenerative ones. Such a review is current as new methods are constantly being developed, concurrent with refinements to those already well established in mainstream anthropology.

Researchers of human remains [5] working at Forensic Anthropology Society of Europe (FASE) and International Academy of Legal Medicine in a scientific article on age estimation focused both on the dead and the living, at highlighting advantages and limits of each method and suggesting practical solutions concerning the age estimation process for adults and subadults, dead and living.

A simple and economical method to analyse human bone remains is with the use of a calliper. The device is used for teeth measurements. Skulls and teeth are often identification material and serve the purpose of analysis and evaluation of dental evidence to identify victims of crimes and accidents. The technique is wildly used in criminology [1].

Studies conducted by Pfeiffer et al. [14] drew attention to the fact that the process of femoral remodelling along mechanical axes of the bone displayed a considerably smaller regional variability than along its anatomical axes. The authors proposed to change the locations of areas where osteons were counted using the abovementioned method in order to avoid miscalculation of the areas of bone to which significant mechanical force had been applied. While developing the study methodology, it was important to consider the area where samples of cortical bone were collected from. This was connected with differences in the dynamics of age-related changes in various bones as well as in various parts of the same bone $[4,13$, $14,17]$. This observation was confirmed by results of studies on the influence of mechanical load or the lack thereof on the rate of bone remodelling process [8, 14]. According to Chan et al. [3] who studied femoral bone, significant differences relating to the rate of remodelling process, which were ascertained in various places of the same bone, were the result of different mechanical loads. Thus, the state of cortical bone reflected its reaction to prolonged pressure and tension. When a given bone or its part did not experience such strain, the total number of osteons was smaller as compared to those parts which showed greater resistance to mechanical factors [8]. All of the above allowed the statement that results of micro-osteometric examinations were heavily dependent on where a given sample was obtained from $[3,4,8,13$, $14,17]$. Locally existing individual osteon variability, which was visible in the context of the whole skeleton as well as of single bones, was a major problem related to the accuracy of age assessment based on bone features.

Recently, advance medical imaging technique such as computed tomography (CT) and magnetic resonance imaging (MRI) were successfully introduced to forensics. CT is also applied in the post-mortem research, especially in the angiography of arteries. It enables to detect exact changes in arteries and veins and determine a source of bleeding in the cases of acute haemorrhages resulting in death [12]. MRI is also applied in forensic medicine to estimate bone age on the basis of clavicles [7]. Analyses of radiological images of clavicles are also used for the identification of dead bodies [2].

The aim of the study was to compare histological sections of bone specimens obtained from different areas of the same bone, the clavicle, and to define an optimum fragment to collect samples for histological examination.

\section{MATERIALS AND METHODS}

The study material were fragments of left clavicles (shafts of clavicles) taken from 39 males and 25 females, aged 22-86 years. The analysed clavicles were extracted from fresh remains (the necropsy was performed 2-3 days after death). The material was acquired during autopsies conducted between 2005-2011 at the Department of Forensic Medicine of Poznan and the Bialystok Medical University, 
Poland. While collecting the clavicles from the remains, it was taken into consideration that the majority of our society was right-handed which meant that the left upper limb as well as the shoulder girdle had fewer changes caused by physical overload. After the removal of soft tissue from the clavicles, a ring-shaped cross section, $5 \mathrm{~mm}$ thick, was taken from half of the shaft's length ( $50 \%$ length) by use of an autopsy saw, which was degreased in a $70 \%$ ethyl alcohol solution $\left(\mathrm{C}_{2} \mathrm{H}_{5} \mathrm{OH}\right)$. After flushing and drying, each of the extracted fragments was encased and glued with $\mathrm{Na}_{2} \mathrm{SiO}_{3}$ to a glass surface of $10 \times 6 \times 0.6 \mathrm{~cm}$ in dimensions. After $24 \mathrm{~h}$ from the gluing, the material was polished manually until obtaining a thickness of 80-110 $\mu \mathrm{m}$. Next the sample was unglued from the glass surface using water, degreased for the second time using $70 \%$ ethyl alcohol solution and immersed using $70 \%, 90 \%$ and $100 \%$ xylene.

The analysis used a Carl Zeiss Axiovert SAF 451210 microscope. The analysis was conducted using transmitted and polarised light with a magnification of $\times 50, \times 100$. The photographs were taken using a Pixelink Megapixel Firewire camera with the Pixelink Cuptura software.

During the examination in the fields of vision, the attention was drawn to such elements of bone microstructure as: number of osteons in the field of vision (ON), number of osteons with the Haversian canal of more than $70 \mu \mathrm{m}$ ( $\mathrm{HC}>70 \mu \mathrm{m})$, average diameter of the Haversian canals (avg. ØHC), area occupied by interstitial lamellae (ILA \%), area occupied by osteons (OA \%), area occupied by fragments-remnants of osteons remaining as irregular arcs of lamellar fragments (OFA \%), average thickness of outer circumferential lamellae, $\mu \mathrm{m}$ (avg. $\mathrm{OCL}$ ), the relation of osteons with the Haversian canal of more than $70 \mu \mathrm{m}$ in diameter to the total number of osteons (HC $>70 \mu \mathrm{m}, \%)$, at $\mathrm{p}<0.00001$.

To conduct the micromorphometric research, 4 fields of vision of a preparation at $\times 50$ enlargement, size of $3019 \times 2415 \mu \mathrm{m}$ and the area of the field of vision of $7.29 \mathrm{~mm}^{2}$ were chosen. The fields of vision situated on the opposite poles of the bone cross-section were analysed: anterior, posterior, upper and lower ones, exactly at the external edge of the bone involving the layers of external bone lamellae as well as the osteon layer of the compact bone. The morphometric analysis was conducted using Image J 1.39u and Photo M 1.31 computer programmes.
The research project and all procedures were approved by the Bioethics Commission (951/08) of the Medical University of Poznan.

\section{Statistical analysis}

Statistical studies were performed on the ratio of osteons with Haversian canal of $>70 \mu \mathrm{m}$ in diameter to the total number of osteons (\%). Each of the obtained parameters was analysed with regard to its statistical significance. Next, they were subjected to analysis of change related to age by using univariate linear regression function. Each of the achieved parameters was analysed taking into account statistical significance. Those ones that were statistically significant were selected and analysed focusing on variability occurring with age using the function of univariate and multivariate linear regression.

The linear regression function: $\mathrm{Y}=\beta_{\mathrm{o}}+\beta_{1} \mathrm{X}+\varepsilon$, where: $Y$ - searched value-age, $X_{1}, X_{2}, \ldots X_{i}$ - predictors, $\mathrm{X}_{1}-\mathrm{ON}_{\mathrm{s}}$ - number of osteons, $\mathrm{X}_{2}-\mathrm{HC}>70 \mu \mathrm{m}$ - number of osteons with the Haversian canal diameter larger than $70 \mu \mathrm{m}, \mathrm{X}_{3}$-avg. $\varnothing \mathrm{HC}$ - average diameter of the Haversian canals, $\mu \mathrm{m}, \mathrm{X}_{4}$-ILA - area occupied by interstitial lamellae (\%), $\mathrm{X}_{5}-\mathrm{OA}$ - area occupied by osteons (\%), $\mathrm{X}_{6}-\mathrm{FRO}$ - area occupied by fragments-remnants after remodelled osteons (\%), $\mathrm{X}_{7}$-avg. $\mathrm{OCL}-$ average thickness of outer circumferential lamellae, $\mathrm{X}_{8}-\mathrm{HC}>70 \mu \mathrm{m}-\%$ relation of the number of osteons with Haversian canal of $>70 \mu \mathrm{m}$ in diameter to the total number of osteons, $\beta_{0}, \beta_{1}, \beta_{2} \ldots \beta_{8}$ - parameters of the function of linear regression, I - the number of analysed features showing statistical significance, $\varepsilon$ - estimation standard error, R - multidimensional correlation coefficient, $\mathrm{R}^{2}$ — determination coefficient - symbolises the percentage of explained age variability by a given feature in a sample, $R^{2}$ - correct - a correction of the determination coefficient for the entire population.

In the model of multivariate regression, the linear equation was calculated using three methods: a standard method (including all predictors), forward stepwise regression (involving adding to the model such predictors that have the biggest influence on age and are least correlated with one another) and backward stepwise regression (involving eliminating from the model composed of all predictors those which have the smallest influence on age). 
All of the verified models of univariate and multivariate linear regression can be used to estimate an approximate age by using a typical linear regression equation: age $=\beta_{0}+\beta_{1} \mathrm{X}_{1}+\beta_{2} \mathrm{X}_{2}+\ldots+\beta_{\mathrm{i}} \mathrm{X}_{\mathrm{i}}+\varepsilon$.

\section{RESULTS}

As a result of the conducted examination, the attention was drawn to the fact that in the individual fields of vision of sections taken from the ends of the clavicle, the number of osteons was significantly higher than in the fields of vision of sections taken from the shaft, and the area of the fields of vision was usually covered by osteons. In clavicle sections of elderly persons, an increasingly greater part of the area was covered by osteon fragments left after the remodelling e.g. interstitial lamellae. In clavicle shafts, it was observed that the areas covered by remnants of remodelled osteons increased with age of the analysed individuals (OFA \%). It was also stated that the number of osteons with a bigger diameter of Haversian canals increased with age, as well. In ground preparations of clavicles derived from older people, the area of field of vision covered by fragments of remodelled osteons increased gradually.

The data presented in the tables concerned only shafts of clavicles. The area was selected to be analysed descriptively due to the fact that the clavicle was least exposed to mechanical factors. It was only influenced mechanically by the subclavian muscle. The achieved results were credible, which enabled to estimate the age of the remains precisely.

The results are presented in Tables $1-3$ and in Figures 1 and 2.

To assess the age of bone remains, the following parameters were taken into account: clavicle length, clavicle width, clavicle thickness, number of osteons in the field of vision, number of osteons with the Haversian canal of more than $70 \mu \mathrm{m}$, average diameter of the Haversian canals, area occupied by interstitial lamellae (\%), area occupied by osteons (\%), area occupied by osteon fragments left after the remodelling, e.g. interstitial lamellae (\%), average thickness of outer circumferential lamellae (\%), the ratio of osteons with the Haversian canal of more than $70 \mu \mathrm{m}$ in diameter to the total number of osteons (\%). After analysing each obtained parameter in 4 fields of vision with a total area of $29.16 \mathrm{~mm}^{2}$ detailed results were obtained and presented in Table 1.

Statistical analysis showed that the features significantly differentiating the age were: the number of osteons in field of vision (ON), number of osteons with the diameter of the Haversian canal larger than $70 \mu \mathrm{m}$ $(\mathrm{HC}>70 \mu \mathrm{m})$, average diameter of the Haversian canal, $\mu \mathrm{m}$ (avg. $\varnothing \mathrm{HC}$ ), area occupied by interstitial lamellae (ILA \%), area occupied by osteons (OA \%), area occupied by osteon fragments left after the remodelling (FO \%), average thickness of outer circumferential lamellae (avg. $\mathrm{OCL}, \mu \mathrm{m}$ ), ratio of osteons with the Haversian canal of more than $70 \mu \mathrm{m}$ in diameter to the total number of osteons ( $\mathrm{HC}>70 \mu \mathrm{m}, \%$ ). The level of statistical significance for the assessment of each of these parameters was $p<0.00001$.

Statistically significant parameters were analysed focusing on variability occurring with age by use of univariate linear regression function allowing determination of the age of the remains both with undetermined sex and taking sex into account. In order to determine the potential diagnostic utility value, the sensitivity of the method for each of the analysed features was also calculated. The univariate linear regression coefficient for the selected parameters is presented in Tables 2 and 3.

The table presents the best predictors of age using univariate linear regression function in a general group and for each sex, which included: the average diameter of the Haversian canals, the ratio of osteons with Haversian canals of more than $70 \mu \mathrm{m}$ in diameter to the general amount of osteons, the percentage of area occupied by interstitial lamellae, the percentage of area occupied by osteon fragments left after the remodelling. Within the female group, each of the analysed parameters showed a higher diagnostic sensitivity. The above mentioned might be connected with more intensely progressing changes in bone structure, which occur in female organisms due to hormonal changes in the menopause and post-menopause periods, as well as with a larger number of women in the age group of 60 and above.

For each analysed feature describing a given value (predictors) in the general group and groups divided by sex, the free coefficient $\left(\beta_{0}\right)$, and the correlation coefficient (R) of a specific model was calculated, as well as a standard estimation error $(\varepsilon)$. The results are shown in Table 3.

All of the verified models of univariate linear regression can be used to predict age using an appropriate equation: Age $=\beta_{0}+\beta \mathrm{X}+\varepsilon$.

\section{DISCUSSION}

Clavicles, and their shafts in particular, constitute very good research material as they are only influenced 
Table 1. Quantity and percentage data obtained in the morphometric study of the clavicle shaft histological sections. The presented data concern only shafts of the clavicle

\begin{tabular}{|c|c|c|c|c|c|c|c|c|c|c|c|c|c|}
\hline No. & $\begin{array}{c}\text { Sex, } \\
\text { male, } \\
\text { female }\end{array}$ & $\begin{array}{c}\text { Age } \\
\text { [years] }\end{array}$ & $\begin{array}{c}\text { Avg. ØНC } \\
{[\mu \mathrm{m}]}\end{array}$ & $\begin{array}{c}\text { CW } \\
{[\mathrm{mm}]}\end{array}$ & $\begin{array}{c}\text { CT } \\
{[\mathrm{mm}]}\end{array}$ & CL & $\begin{array}{l}\mathrm{HC}>70 \\
\text { [amount] }\end{array}$ & $\begin{array}{c}\text { ON } \\
\text { [amount] }\end{array}$ & $\begin{array}{l}\text { ILA } \\
{[\%]}\end{array}$ & $\begin{array}{l}\text { OA } \\
{[\%]}\end{array}$ & $\begin{array}{l}\text { OFA } \\
{[\%]}\end{array}$ & $\begin{array}{l}\text { Avg. } \\
\text { OCL }\end{array}$ & $\begin{array}{c}\mathrm{HC}>70 \\
{[\%]}\end{array}$ \\
\hline 1 & $\mathrm{~F}$ & 60 & 59 & 10.4 & 9 & 143 & 30 & 148 & 4.1 & 30.4 & 65.5 & 77.8 & 20.2 \\
\hline 2 & $M$ & 40 & 38.1 & 10.8 & 9.8 & 148 & 5 & 104 & 22.1 & 24.6 & 53.3 & 160 & 4.8 \\
\hline 3 & $M$ & 40 & 44.8 & 11 & 10 & 150 & 8 & 116 & 20 & 32.3 & 47.7 & 112 & 6.9 \\
\hline 4 & $\mathrm{M}$ & 47 & 42.5 & 12 & 10 & 161 & 8 & 92 & 8.2 & 20.3 & 71.8 & 98.8 & 8.6 \\
\hline 5 & $M$ & 46 & 46.8 & 11 & 9 & 146 & 16 & 120 & 12.3 & 26.7 & 61 & 88 & 13.3 \\
\hline 6 & $M$ & 40 & 37.9 & 12 & 9.2 & 151 & 5 & 106 & 24.3 & 27.1 & 48.6 & 138 & 4.7 \\
\hline 7 & $\mathrm{~F}$ & 66 & 60.2 & 10 & 8.8 & 133 & 32 & 148 & 3.1 & 28 & 68.9 & 72.2 & 21.6 \\
\hline 8 & $M$ & 33 & 44.5 & 10.3 & 9 & 142 & 12 & 112 & 18.6 & 35.1 & 46.3 & 104 & 10.7 \\
\hline 9 & $\mathrm{~F}$ & 73 & 70.1 & 10.2 & 9 & 148 & 30 & 128 & 4.8 & 30.6 & 64.6 & 76.2 & 23.4 \\
\hline 10 & $F$ & 25 & 32.8 & 10 & 8 & 144 & 6 & 104 & 21 & 39.3 & 39.7 & 116 & 5.7 \\
\hline 11 & $M$ & 54 & 54.5 & 12 & 9.2 & 140 & 22 & 130 & 4.8 & 18.7 & 76.5 & 71.6 & 16.9 \\
\hline 12 & $M$ & 44 & 44.6 & 11 & 7.7 & 146 & 5 & 118 & 9.4 & 30.2 & 60.4 & 102 & 4.2 \\
\hline 13 & $\mathrm{~F}$ & 39 & 36.8 & 10.2 & 9.8 & 136 & 8 & 112 & 14.7 & 30.5 & 54.8 & 98 & 7.1 \\
\hline 14 & $\mathrm{~F}$ & 42 & 51.9 & 10.4 & 10.1 & 140 & 20 & 118 & 6.4 & 34.6 & 59 & 104 & 16.9 \\
\hline 15 & $M$ & 32 & 32.6 & 11 & 9 & 142 & 3 & 104 & 23.5 & 38.6 & 37.9 & 128.6 & 2.8 \\
\hline 16 & $M$ & 23 & 32.2 & 10.3 & 8.8 & 131 & 2 & 90 & 14.6 & 36.8 & 48.6 & 122 & 2.2 \\
\hline 17 & $M$ & 48 & 47.2 & 11.1 & 8.6 & 144 & 16 & 121 & 5.3 & 28 & 66.7 & 84.6 & 13.2 \\
\hline 18 & $\mathrm{~F}$ & 76 & 70.8 & 11 & 9.2 & 150 & 32 & 122 & 3.4 & 23.5 & 73.1 & 37.7 & 26.2 \\
\hline 19 & $\mathrm{~F}$ & 78 & 76.6 & 10.1 & 9.2 & 137 & 38 & 148 & 1.4 & 27.6 & 70 & 40.2 & 25.6 \\
\hline 20 & $M$ & 44 & 41.8 & 10.3 & 9.8 & 152 & 24 & 154 & 12.1 & 32.1 & 55.8 & 112 & 15.6 \\
\hline 21 & $M$ & 40 & 42.5 & 11.5 & 8.2 & 144 & 4 & 97 & 21 & 29.3 & 49.7 & 120 & 9.2 \\
\hline 22 & $M$ & 67 & 68.4 & 10.2 & 9 & 146 & 30 & 128 & 6.2 & 26.8 & 67 & 82.7 & 23.4 \\
\hline 23 & $F$ & 56 & 56.6 & 11 & 9.2 & 138 & 30 & 146 & 4.9 & 31.2 & 63.9 & 102 & 20.5 \\
\hline 24 & $\mathrm{M}$ & 35 & 38.1 & 13 & 9.8 & 152 & 4 & 97 & 22.8 & 38.8 & 38.4 & 110 & 4.1 \\
\hline 25 & $\mathrm{~F}$ & 48 & 52.9 & 10.2 & 9.2 & 140 & 25 & 130 & 5.2 & 30.5 & 64.3 & 114 & 19.2 \\
\hline 26 & $M$ & 49 & 54.5 & 11 & 10 & 142 & 18 & 134 & 9.8 & 20.8 & 69.4 & 73.8 & 13.4 \\
\hline 27 & $\mathrm{~F}$ & 22 & 34.8 & 12 & 8.8 & 134 & 4 & 98 & 20.8 & 45.8 & 35.4 & 142 & 4.1 \\
\hline 28 & $M$ & 69 & 64 & 12.4 & 12 & 152 & 23 & 116 & 9.7 & 13.4 & 76.9 & 111 & 19.8 \\
\hline 29 & $M$ & 22 & 36.2 & 12 & 9.8 & 146 & 5 & 105 & 23.8 & 21.3 & 54.9 & 217 & 4.7 \\
\hline 30 & $M$ & 58 & 61.3 & 14 & 10.1 & 146 & 23 & 126 & 5.8 & 24.8 & 69.4 & 102 & 18.2 \\
\hline 31 & $M$ & 47 & 38.6 & 11 & 9 & 142 & 6 & 109 & 7.7 & 14 & 78.3 & 71.5 & 5.5 \\
\hline 32 & $M$ & 52 & 47.2 & 13 & 9.8 & 151 & 8 & 111 & 8.5 & 19.3 & 73.2 & 80.2 & 7.2 \\
\hline 33 & $\mathrm{M}$ & 58 & 37.4 & 11.1 & 8.6 & 144 & 6 & 135 & 7 & 15.8 & 77.2 & 113 & 4.4 \\
\hline 34 & $\mathrm{~F}$ & 24 & 36.6 & 11 & 9.2 & 150 & 4 & 106 & 23 & 48 & 29 & 126 & 3.7 \\
\hline 35 & $M$ & 40 & 39.6 & 14.2 & 10 & 157 & 6 & 124 & 18.9 & 31.6 & 49.5 & 104 & 4.8 \\
\hline 36 & $M$ & 50 & 56.2 & 16.4 & 10.6 & 150 & 14 & 140 & 7.2 & 26.6 & 66.2 & 84.8 & 10 \\
\hline 37 & $\mathrm{M}$ & 81 & 77.5 & 14.2 & 10.1 & 151 & 48 & 142 & 2.8 & 18.3 & 78.9 & 68.8 & 33.8 \\
\hline 38 & $\mathrm{~F}$ & 61 & 78.2 & 14 & 9 & 132 & 36 & 145 & 2.6 & 27.5 & 69.9 & 94.75 & 24.8 \\
\hline 39 & $M$ & 76 & 64.7 & 14 & 10.5 & 142 & 33 & 108 & 3.4 & 18.2 & 78.4 & 48.3 & 30.5 \\
\hline 40 & $\mathrm{M}$ & 70 & 68.2 & 12.6 & 12 & 150 & 35 & 142 & 2.6 & 20.1 & 77.3 & 92.2 & 24.6 \\
\hline 41 & $F$ & 91 & 71.1 & 11 & 9 & 146 & 30 & 114 & 1.3 & 18.8 & 79.9 & 23.6 & 26.3 \\
\hline 42 & $M$ & 22 & 28.8 & 10.3 & 8.9 & 140 & 2 & 98 & 29.6 & 37.2 & 33.2 & 160 & 2 \\
\hline
\end{tabular}


Table 1. (cont.) Quantity and percentage data obtained in the morphometric study of the clavicle shaft histological sections. The presented data concern only shafts of the clavicle

\begin{tabular}{|c|c|c|c|c|c|c|c|c|c|c|c|c|c|}
\hline No. & $\begin{array}{c}\text { Sex, } \\
\text { male, } \\
\text { female }\end{array}$ & $\begin{array}{c}\text { Age } \\
\text { [years] }\end{array}$ & $\begin{array}{c}\text { Avg. ØHC } \\
{[\mu \mathrm{m}]}\end{array}$ & $\begin{array}{c}\text { CW } \\
{[\mathrm{mm}]}\end{array}$ & $\begin{array}{c}\text { CT } \\
{[\mathrm{mm}]}\end{array}$ & CL & $\begin{array}{l}\mathrm{HC}>70 \\
\text { [amount] }\end{array}$ & $\begin{array}{c}\text { ON } \\
\text { [amount] }\end{array}$ & $\begin{array}{l}\text { ILA } \\
{[\%]}\end{array}$ & $\begin{array}{l}\mathbf{O A} \\
{[\%]}\end{array}$ & $\begin{array}{l}\text { OFA } \\
{[\%]}\end{array}$ & $\begin{array}{l}\text { Avg. } \\
\text { OCL }\end{array}$ & $\begin{array}{c}\text { HC > } 70 \\
{[\%]}\end{array}$ \\
\hline 43 & $M$ & 23 & 34.4 & 10.2 & 9.1 & 139 & 2 & 88 & 26.8 & 40.3 & 32.9 & 140.6 & 2.2 \\
\hline 44 & $\mathrm{~F}$ & 59 & 55.2 & 11.5 & 8 & 135 & 22 & 152 & 7.2 & 32.1 & 60.7 & 102 & 14.4 \\
\hline 45 & $F$ & 53 & 66 & 11 & 9 & 137 & 28 & 110 & 12.6 & 25.8 & 61.6 & 120 & 25.4 \\
\hline 46 & $\mathrm{~F}$ & 64 & 73.1 & 10.6 & 8.5 & 133 & 38 & 124 & 2.8 & 29.1 & 68.1 & 59.8 & 30.6 \\
\hline 47 & $\mathrm{~F}$ & 73 & 76.3 & 11.2 & 9.1 & 138 & 36 & 112 & 2.3 & 26.4 & 71.3 & 52.2 & 32.1 \\
\hline 48 & $\mathrm{~F}$ & 25 & 33.6 & 12 & 8 & 124 & 4 & 98 & 22.8 & 33.6 & 43.6 & 102 & 4.1 \\
\hline 49 & $M$ & 29 & 33.3 & 11 & 9 & 140 & 4 & 102 & 26.2 & 29 & 44.8 & 162 & 3.9 \\
\hline 50 & $M$ & 29 & 32.2 & 12.5 & 9 & 143 & 2 & 78 & 28.3 & 26.2 & 45.5 & 146.2 & 2.5 \\
\hline 51 & $\mathrm{~F}$ & 38 & 42.8 & 11.2 & 8.8 & 136 & 20 & 122 & 12.8 & 34.8 & 52.4 & 136 & 16.3 \\
\hline 52 & $M$ & 28 & 35.4 & 12 & 9.2 & 145 & 4 & 96 & 20.1 & 42.8 & 37.1 & 158 & 4.1 \\
\hline 53 & $M$ & 41 & 46.6 & 13.8 & 9 & 152 & 8 & 138 & 20.8 & 34.7 & 45.5 & 98 & 5.7 \\
\hline 54 & $\mathrm{~F}$ & 61 & 66.2 & 12 & 9.7 & 135 & 24 & 132 & 3.6 & 30.4 & 66 & 75.5 & 17.9 \\
\hline 55 & $\mathrm{~F}$ & 22 & 32.2 & 10.2 & 8.8 & 144 & 3 & 90 & 25.5 & 42.7 & 31.8 & 118 & 3.3 \\
\hline 56 & $M$ & 29 & 35.4 & 12.8 & 9.2 & 144 & 3 & 90 & 25.9 & 32.8 & 41.3 & 151 & 3.3 \\
\hline 57 & $\mathrm{~F}$ & 22 & 34 & 13 & 8.8 & 138 & 3 & 98 & 26 & 38.9 & 35.1 & 110 & 3 \\
\hline 58 & $M$ & 30 & 36.8 & 14.5 & 9.2 & 149 & 4 & 84 & 25 & 26 & 49 & 160 & 4.7 \\
\hline 59 & $M$ & 56 & 69.4 & 14 & 9 & 145 & 32 & 138 & 3.2 & 20.6 & 76.2 & 64.8 & 23.2 \\
\hline 60 & $\mathrm{~F}$ & 53 & 49.5 & 14 & 9.7 & 130 & 24 & 112 & 3.6 & 30.4 & 66 & 75.5 & 21.4 \\
\hline 61 & $M$ & 54 & 61.3 & 14.2 & 9 & 144 & 12 & 152 & 4.3 & 22.8 & 72.9 & 82.2 & 7.8 \\
\hline 62 & $M$ & 69 & 63.7 & 14.5 & 9.6 & 170 & 28 & 156 & 3.8 & 22.9 & 73.3 & 102 & 17.9 \\
\hline 63 & $F$ & 86 & 68.4 & 15.4 & 8.4 & 163 & 38 & 94 & 3 & 26.1 & 70.9 & 54.2 & 40.8 \\
\hline 64 & $M$ & 35 & 37.7 & 13.3 & 11 & 154 & 6 & 94 & 25.8 & 14.9 & 59.3 & 132.3 & 6.3 \\
\hline
\end{tabular}

$\mathrm{M}$ - male, $\mathrm{F}$ - female, avg. $\emptyset \mathrm{HC}$ - average diameter of the Haversian canals; $\mathrm{CW}$ — clavicle width; $\mathrm{CT}$ — clavicle thickness; $\mathrm{CL}$ - clavicle length; $\mathrm{HC}>70$ [amount] — number of osteons with the Haversian canal of more than $70 \mu \mathrm{m} ; \mathrm{ON}$ — number of osteons; ILA — area occupied by interstitial lamellae; OA — area occupied by osteons; OFA — area occupied by fragments — remains after remodelled osteons; avg. $\mathrm{OCL}$ — average thickness of outer circumferential lamellae; $\mathrm{HC}>70 \mu \mathrm{m}$ [\%] — the ratio of osteons with the Haversian canal of more than $70 \mu \mathrm{m}$ in diameter to the total number of osteons

Table 2. One-dimensional linear regression coefficient for each of the selected diagnostic parameters. The presented data concern only shafts of the clavicle

\begin{tabular}{|c|c|c|c|c|c|c|}
\hline \multirow[t]{2}{*}{ Studied parameter } & \multicolumn{2}{|c|}{ General group } & \multicolumn{2}{|c|}{ Males } & \multicolumn{2}{|c|}{ Females } \\
\hline & $\mathbf{R}^{2}[\%]$ & $\mathbf{R}^{2}$ corr. [\%] & $\mathbf{R}^{2}[\%]$ & $\mathbf{R}^{2}$ corr. [\%] & $\mathbf{R}^{2}[\%]$ & $\mathbf{R}^{2}$ corr. [\%] \\
\hline ON & 34.3 & 33.3 & 46.01 & 44.55 & 22.61 & 19.24 \\
\hline $\mathrm{HC}>70 \mu \mathrm{m}$ & 76.62 & 76.25 & 73.78 & 73.09 & 83.05 & 82.31 \\
\hline Avg. ØHC & 82.33 & 82.04 & 80.27 & 79.73 & 83.62 & 82.91 \\
\hline ILA & 75.33 & 74.93 & 73.13 & 72.40 & 80.96 & 80.13 \\
\hline$O A$ & 35.94 & 34.90 & 42.46 & 40.90 & 75.66 & 74.60 \\
\hline OFA & 73.74 & 73.32 & 74.06 & 73.36 & 86.70 & 86.12 \\
\hline Avg. OCL & 62.66 & 62.06 & 55.36 & 54.15 & 74.77 & 73.67 \\
\hline $\mathrm{HC}>70 \mu \mathrm{m}[\%]$ & 76.81 & 76.44 & 74.12 & 73.42 & 81.71 & 80.92 \\
\hline
\end{tabular}

Abbreviations as in Table 1. 
Table 3. A cumulative breakdown of age estimation using one-dimensional regression analysis. The presented data concern only shafts of the clavicle

\begin{tabular}{|c|c|c|c|c|c|c|}
\hline & $\begin{array}{c}\begin{array}{c}\text { Free } \\
\text { coefficient } \\
\beta 0\end{array} \\
\beta_{0}\end{array}$ & $\begin{array}{c}\text { Regression } \\
\text { coefficient } \\
\beta\end{array}$ & $\begin{array}{l}\text { Estimation } \\
\text { error } \\
\varepsilon\end{array}$ & $\begin{array}{l}\text { Correlation } \\
\text { coefficient } \\
\text { R }\end{array}$ & $\begin{array}{c}\text { Determination } \\
\text { coefficient } \\
\text { R }^{2}, \%\end{array}$ & $\begin{array}{c}\text { Corrected } \\
\text { determination } \\
\text { coefficient } \\
\mathbf{R}^{2}, \%\end{array}$ \\
\hline Number of osteons & -14.03 & 0.52 & 14.9 & 0.58 & 34.3 & 33.3 \\
\hline $\begin{array}{l}\text { Male } \\
\text { Female }\end{array}$ & $\begin{array}{l}-13.18 \\
-10.86\end{array}$ & $\begin{array}{l}0.50 \\
0.52\end{array}$ & $\begin{array}{l}11.5 \\
19.1\end{array}$ & $\begin{array}{l}0.67 \\
0.47\end{array}$ & $\begin{array}{l}46.01 \\
22.61\end{array}$ & $\begin{array}{l}44.55 \\
19.24\end{array}$ \\
\hline $\begin{array}{l}\text { Number of osteons } \\
\text { with diameter }>70 \mu \mathrm{m}\end{array}$ & 27.27 & 1.24 & 8.9 & 0.87 & 76.62 & 76.25 \\
\hline $\begin{array}{l}\text { Male } \\
\text { Female }\end{array}$ & $\begin{array}{l}30.17 \\
17.93\end{array}$ & $\begin{array}{l}1.14 \\
1.53\end{array}$ & $\begin{array}{l}8.0 \\
8.9\end{array}$ & $\begin{array}{l}0.85 \\
0.91\end{array}$ & $\begin{array}{l}73.78 \\
83.05\end{array}$ & $\begin{array}{l}73.09 \\
82.31\end{array}$ \\
\hline $\begin{array}{l}\text { Average diameter } \\
\text { of the Haversian canals }\end{array}$ & -8.29 & 1.12 & 7.7 & 0.90 & 82.33 & 82.04 \\
\hline $\begin{array}{l}\text { Male } \\
\text { Female }\end{array}$ & $\begin{array}{l}-5.32 \\
-14.53\end{array}$ & $\begin{array}{l}1.07 \\
1.21\end{array}$ & $\begin{array}{l}6.9 \\
8.8\end{array}$ & $\begin{array}{l}0.89 \\
0.91\end{array}$ & $\begin{array}{l}80.27 \\
83.62\end{array}$ & $\begin{array}{l}79.73 \\
82.91\end{array}$ \\
\hline $\begin{array}{l}\text { Per cent area of interstitial } \\
\text { lamellae }\end{array}$ & 69.87 & -1.73 & 9.1 & 0.86 & 75.33 & 74.93 \\
\hline $\begin{array}{l}\text { Male } \\
\text { Female }\end{array}$ & $\begin{array}{l}66.39 \\
73.98\end{array}$ & $\begin{array}{l}-1.47 \\
-2.23\end{array}$ & $\begin{array}{l}8.1 \\
9.5\end{array}$ & $\begin{array}{l}0.85 \\
0.89\end{array}$ & $\begin{array}{l}73.13 \\
80.96\end{array}$ & $\begin{array}{l}72.40 \\
80.13\end{array}$ \\
\hline $\begin{array}{l}\text { Per cent area of } \\
\text { osteons with } \\
\text { no remodelling }\end{array}$ & 87.83 & -1.39 & 14.7 & 0.59 & 35.94 & 34.90 \\
\hline $\begin{array}{l}\text { Male } \\
\text { Female }\end{array}$ & $\begin{array}{c}78.92 \\
139.41\end{array}$ & $\begin{array}{l}-1.28 \\
-2.72\end{array}$ & $\begin{array}{l}11.8 \\
10.7\end{array}$ & $\begin{array}{l}0.65 \\
0.86\end{array}$ & $\begin{array}{l}42.46 \\
75.66\end{array}$ & $\begin{array}{l}40.90 \\
74.60\end{array}$ \\
\hline $\begin{array}{l}\text { Per cent area of } \\
\text { fragments after } \\
\text { remodelled osteons }\end{array}$ & -15.15 & 1.07 & 9.4 & 0.85 & 73.74 & 73.32 \\
\hline $\begin{array}{l}\text { Male } \\
\text { Female }\end{array}$ & $\begin{array}{l}-7.89 \\
-27.60\end{array}$ & $\begin{array}{c}-7.89 \\
1.37\end{array}$ & $\begin{array}{l}0.89 \\
7.9\end{array}$ & $\begin{array}{c}7.9 \\
0.93\end{array}$ & $\begin{array}{c}0.86 \\
86.70\end{array}$ & $\begin{array}{l}74.06 \\
86.12\end{array}$ \\
\hline $\begin{array}{l}\text { Average thickness of } \\
\text { outer circumferential } \\
\text { lamellae }\end{array}$ & 89.75 & -0.40 & 11.2 & 0.79 & 62.66 & 62.06 \\
\hline $\begin{array}{l}\text { Male } \\
\text { Female }\end{array}$ & $\begin{array}{c}81.35 \\
104.04\end{array}$ & $\begin{array}{l}-0.32 \\
-0.57\end{array}$ & $\begin{array}{l}10.4 \\
10.9\end{array}$ & $\begin{array}{l}0.74 \\
0.86\end{array}$ & $\begin{array}{l}55.36 \\
74.77\end{array}$ & $\begin{array}{l}54.15 \\
73.67\end{array}$ \\
\hline $\begin{array}{l}\text { Per cent of osteons with } \\
\text { a diameter }>70 \mu \mathrm{m}\end{array}$ & 26.22 & 1.61 & 8.8 & 0.87 & 76.81 & 76.44 \\
\hline $\begin{array}{l}\text { Male } \\
\text { Female }\end{array}$ & $\begin{array}{l}28.30 \\
18.81\end{array}$ & 1.59 & $\begin{array}{l}7.9 \\
93\end{array}$ & $\begin{array}{l}0.86 \\
0.9 n\end{array}$ & $\begin{array}{l}74.12 \\
8171\end{array}$ & $\begin{array}{l}73.42 \\
80.92\end{array}$ \\
\hline
\end{tabular}

mechanically by the subclavian muscle. Thus, clavicles are not loaded mechanically and similarly to teeth [1] and tibial bones, it is possible to estimate changes in the structure of the osseous tissue influenced by diseases and metabolic disorders. Besides, clavicles can be used to evaluate age in juveniles and adults [6].

The choice of left clavicles for the experiment was due to a commonly known statement that the majority of population is right-handed and the microscopic image of bone is to a great degree dependent on the effect of mechanical forces which a bone is subject to
$[8,9]$. The acromial end area is vulnerable to forces from ligamentum conoideum and muscles: musculus deltoideus, m. subclavius, and m. trapezius; whereas the sternal end area is subject to forces from l. costoclaviculare and muscles: $\mathrm{m}$. pectoralis maior and $\mathrm{m}$. sternocleidomastoideus. In the place of bone sample collection in the clavicle shaft area, mechanical force is applied only by $\mathrm{m}$. subclavius [8]. Our research presents the differences in the structure of the histological remodelling of the shaft of the clavicle depending on age and sex. The abovementioned fact was also confirmed 


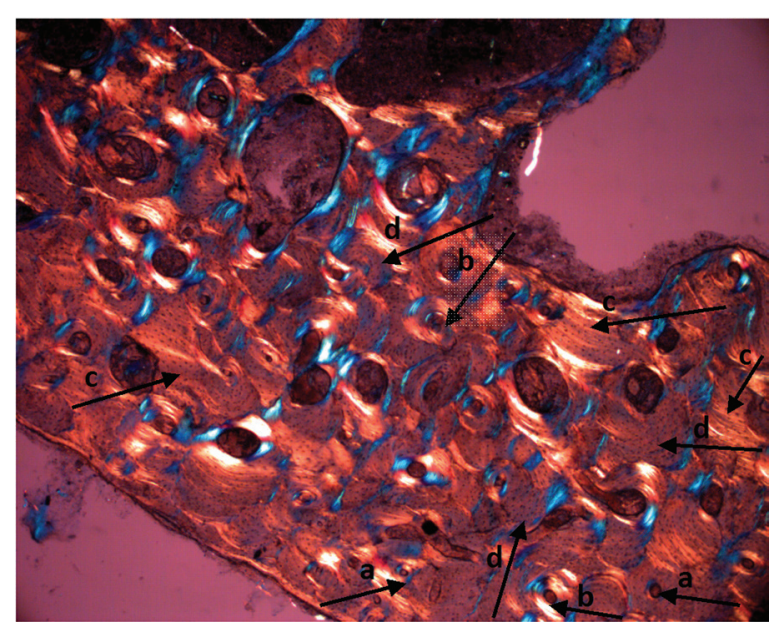

A
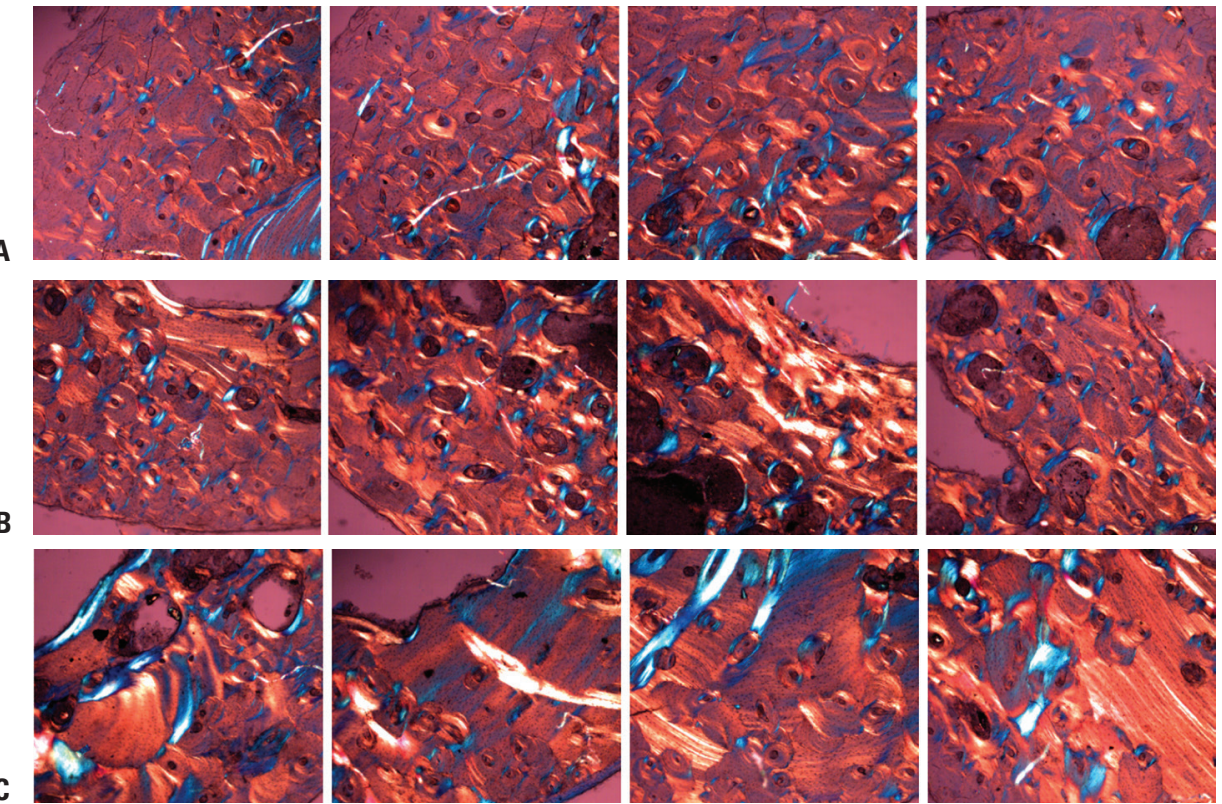

Figure 1. Analysed field of vision of a ground preparation of the lateral end of a clavicle of a man aged 33; a — primary osteons; $b-\mathrm{se}$ condary osteons; c - interstitial lamellae; $d$ - remains after remodelled osteons; A. Analysed fields of vision of a ground preparation of the shaft of a clavicle of a man aged 33; B. Analysed fields of vision of a ground preparation of the paracentral end of a clavicle of a man aged 33; C. Analysed fields of vision of a ground preparation of the lateral end of a clavicle of a man aged 33.

in the studies by Chan et al. [3] who reported the same findings in different locations of the bone due to various mechanical loads [16].

Ingraham [10] took into account four parameters of the microscopic structure of the clavicle: the number of primary and secondary osteons, percentage area occupied by interstitial lamellae and the percentage area occupied by osteon fragments left after the remodelling. Similarly to Ingraham [10], we took into consideration the above mentioned 4 parameters, but also added the number of osteons with the diameter of the Haversian canal larger than $70 \mu \mathrm{m}$, average diameter of the Haversian canal, area occupied by osteons, average thickness of outer circumferential lamellae, ratio of osteons with the Haversian canal of more than $70 \mu \mathrm{m}$ in diameter to the total number of osteons. As a result of introducing linear regression equations, the obtained result had a determination coefficient of $87.1 \%$, and the standard estimation error was \pm 6.7 years. The authors of the present elaboration, using the multivariate regression equation and taking into account all statistically significant parameters, calculated the coefficient of determination - $90.52 \%$, the estimation error amounted to \pm 5.6 years. Favourable locations to obtain a bone for analysis were segments situated most distantly from the muscle and ligament attachment areas. The segments were at the shaft as their microscopic examination significantly reduced the risk of inaccurate interpretation 


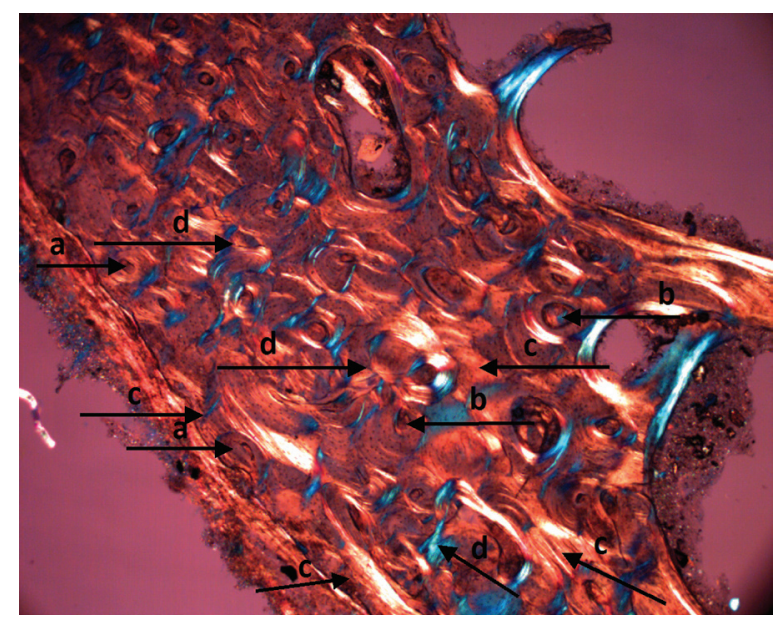

A
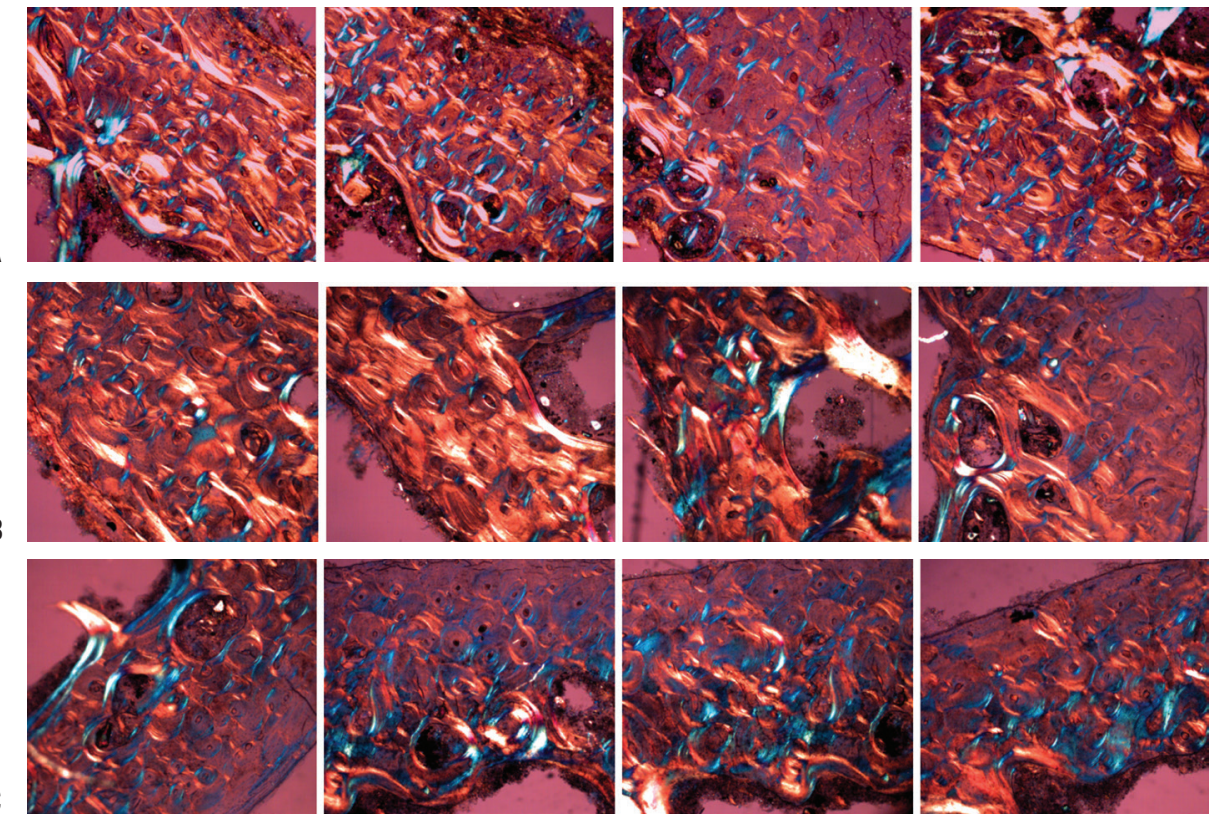

Figure 2. Analysed fields of vision of a ground preparation of the lateral end of a clavicle of a man aged $54 ; a$ - primary osteons; $b-$ secondary osteons; $\mathrm{C}$ - interstitial lamellae; $\mathrm{d}$ - remains after remodelled osteons; A. Analysed fields of vision of a ground preparation of the shaft of a clavicle of a man aged 54; B. Analysed fields of vision of a ground preparation of the paracentral end of a clavicle of a man aged 54; C. Analysed fields of vision of a ground preparation of the lateral end of a clavicle of a man aged 54.

of outcomes which might result from mechanical force factor affecting the microstructure of the bone.

Our research also confirmed that the most suitable area to collect the material was the shaft of the clavicle, as it was only subclavian muscle that influenced it mechanically. The achieved results were credible, which enabled to estimate the age of the remains precisely.

Franklin [6] confirmed that developing new research methods in forensic medicine was by all means justified. It was also emphasised that the estimation of bone age on the basis of development and later degeneration of the skeleton was and still is present [6].
Franklin [6] in his review article presented numerous techniques to estimate age in juveniles and adults. Dental and skeletal methods are generally the primary means used to estimate age in the juvenile skeleton; whereas age estimation in adults, in the absence of key developmental markers, depends on the more highly variable degeneration of bones. This is further complicated by the fact that individualistic factors (e.g. lifestyle, health and nutrition) can influence skeletal remodelling throughout life, introducing an extra source of bias into the final assessment. Different parts of the skeleton (os coxae, ribs, cranial sutures) can thus 'age' at different rates, both between and within individuals. Franklin [6] pointed out the 
possibility of applying clinical images, such as radiographs, CT scans and MRI are already proving to be a promising complementary source of data especially as many forensic institutes now routinely use medical scanning devices for post-mortem examinations.

Dental forensics forms a vital branch of forensic science which deals with proper handling, examination and evaluation of dental evidences for identification of victims of crime, accidents or calamities. Therefore skull and teeth often provide the identification material. The aim of the study was to investigate the accuracy of odontometric methods in sex determination of permanent teeth and to compute new formula to differentiate male and female teeth using discriminant function analysis for South Indian population. A digital Vernier calliper was used for the measurement of teeth. Sexual dimorphism was observed in the size of permanent teeth between the analysed populations. Thus the norms established for one population cannot be applied to another one. Therefore, the techniques suggested will be simpler and more precise for sex determination [1].

Hillewig et al. [7] estimated the age of remains analysing clavicles according to Schmeling and Kreitner classification $[11,15]$. They claimed that clavicles could be used for distinguishing young people and adults older than 18 . They stated that the descriptive results were concordant with the literature, although the Kreitner classification was recommended and simultaneous evaluation of the hand was considered a basic requirement [15]. The $95 \%$ credibility interval for both genders with bilateral stage IV was the age of 20-26. The corresponding estimated probability of being younger than 18 was $0.8 \%$ in females and $0.2 \%$ in males [7]. Hillewig et al. [7] conducted the analysis of clavicles of living organisms, whereas our research concerned clavicles collected from the dead, which can have a broader application while estimating the age of remains in forensic medicine and criminology.

Benito et al. [2] stated that age-at-death estimation in adult individuals was one of the most challenging issues in forensic anthropology, namely, due to the large age intervals provided by the current methods, which required the development of more reliable investigations. Three indices were calculated at the mid-diaphysis point (anterior index, posterior index, and total index) which related the cortical thickness and the total clavicle thickness to age at death. The average grey level was also calculated in a $0.5-\mathrm{cm}$ area of the sternal and acromial ends (sternal grey average, acromial grey average), using Image J software. It was found [2] that average grey level had a weaker correlation with age than the variables which were based on the cortical thickness. On the other hand, the regression equations, which were calculated combining all the variables, provided smaller age-at-death intervals, demonstrating the usefulness of this method for adult age-at-death estimation in forensic anthropology. Thus, it should be emphasised that our research of ground preparation of clavicles complemented previous data concerning the usefulness of clavicle research for age estimation [2]. Therefore, making ground preparations is the most suitable method to prepare the osseous tissue to microscopic analysis aiming at assessing the age of human remains. The method guarantees preserving the shape and sizes of the elements of histological structure of the osseous tissue. It also limits the occurrence of artefacts. The best area for the analysis is the shaft of the clavicle as the possibility of misinterpretation of research results caused by the influence of mechanical factor on the microstructure of the bone is limited.

The authors compared histological image of preparations of the osseous tissue extracted from various areas of the clavicle. Our method of comparing histological image of the clavicle shafts provided a more detailed description of such parameters as the number of osteons, the area covered by osteons, the area occupied by osteon fragments and the remnants of transformed osteons and the area covered by interstitial lamellae. It was more accurate and more detailed as it presented the whole process of the remodelling of the osseous tissue as influenced by age.

The preparations made consisted of ground preparations of the clavicle shafts, ground preparations of the bone between the proximal end and the shaft of the clavicle as well as ground preparations of the bone between the distal end and the shaft of the clavicle.

An important element of our method was to apply appropriate linear regression equations. The best predicators of age with the use of univariate linear regression function for a general group as well as for both sexes were: the average diameter of the Haversian canals, the number of osteons with the diameter of Haversian canals larger than $70 \mu \mathrm{m}$, the ratio of osteons with the diameter of the Haversian canals larger than $70 \mu \mathrm{m}$ to the total amount of osteons, the percentage of area occupied by interstitial lamellae, the percentage of area occupied by osteon fragments left after the remodelling. The suggested 
measurement parameters for microscopic analysis of osseous tissue and their usage in appropriate linear regression equations were precise enough to have regular usage in court ordered medical examinations.

\section{CONCLUSIONS}

It was determined that the number of osteons with a larger diameter of Haversian canals increases with age. This occurrence could be explained by an increase with age of the number of osteons being in resorption phase during which the diameter of the Haversian canals increases due to activity of the osteoclasts and the resorption of osteon's lamellae.

The best area for bone extraction was the segment situated most distally from the area of muscle and tendon insertion, i.e. the shaft. The use of the old method of obtaining bone ground preparations ensured that the shape and size of histological elements of the osseous tissue structure were preserved. It limits creation of artefacts imposed by traditional histological techniques (bone fixation and de-mineralisation) which also last much longer.

The achieved results of microscopic analysis of the osseous tissue of left clavicles allowed to estimate the age of remains with the use of univariate linear regression equations age $=\beta_{0}+\beta X+\varepsilon$. The suggested measurement parameters are exact enough and may have practical use in forensic and medical assessment.

\section{REFERENCES}

1. Anuthama K, Shankar S, Ilayaraja V, Kumar GS, Rajmohan M, Vignesh (2011) Determining dental sex dimorphism in South Indians using discriminant function analysis. Forensic Sci Int, 212: 86-89.

2. Benito M, Sánchez JA, Codinha S (2014) Age-at-death estimation based on radiological and image analysis methods in clavicle in a current Spanish population. Int J Legal Med, 128: 523-533.

3. Chan AH, Crowder CM, Rogers TL (2007) Variation in cortical bone histology within the human femur and its impact on estimating age at death. AJPA, 132: 80-88.
4. Cool SM, Hendrikz JK, Wood WB (1995) Microscopic age changes in the human occipital bone. J Forensic Sci, 40: 789-796.

5. Cunha E, Baccino E, Martrille L, Ramsthaler F, Prieto J, Schuliar Y, Lynnerup N, Cattaneo C (2009) The problem of aging human remains and living individuals: a review. Forensic Sci Int, 193:1-13.

6. Franklin D (2010) Forensic age estimation in human skeletal remains: current concepts and future directions. Leg Med, 12: 1-7.

7. Hillewig E, Degroote J, Van der Paelt T, Visscher A, Vandemaele P, Lutin B, D'Hooghe L, Vandriessche V, Piette M, Verstraete $K$ (2013) Magnetic resonance imaging of the sternal extremity of the clavicle in forensic age estimation: towards more sound age estimates. Int J Legal Med, 127: 677-689.

8. Ilizarow GA (1989) The tension-stress effect on the genesis and growth of tissues. Part I. The influence of stability of fixation and soft-tissue preservation. Clin Orthop, 238: 249-281.

9. Ilizarow GA (1989) The tension-stress effect on the genesis and growth of tissues. Part II. The influence of rate and frequency of distraction. Clin Orthop, 239: 263-285.

10. Ingraham MR (2004) Histological age estimation of the midshaft clavicle using a new digital technique. Thesis prepared for the degree of master of science. Texas, 35.

11. Kreitner KF, Schweden FJ, Ripert T, Nate B, Thelen M (1998). Bone age determination based on the study of the medial extremity of the clavicle. Eur Radiol, 8: 1116-1122.

12. Palmiere C, Binaghi S, Doenz F, Bize P, Chevallier C, Mangin $P$, Grabherr S (2012) Detection of hemorrhage source: the diagnostic value of post-mortem CT-angiography, Forensic Sci Int, 222: 33-39.

13. Parfitt AM (1983) The physiologic and clinical significance of bone histomorphometric data. In: Recker RR ed. Bone histomorphometry, techniques and interpretation. CRC Press, Boca Raton, pp. 143-222.

14. Pfeiffer S, Lazenby R, Chiang J (1995) Brief communication: cortical remodeling data are affected by sampling location. Am J Phys Anthropol, 96: 89-92.

15. Schmeling A, Schulz R, Reisinger W, Mühler M, Wernecke K-D, Geserick G (2004) Studies on the time frame for ossification of medial clavicular epiphyseal cartilage in conventional radiography. Int J Legal Med, 118: 5-8.

16. Stout SD (1982) The effects of long-term in mobilization on the histomorphology of human cortical bone. Calcif Tissue Int, 34: 337-342.

17. Thompson DD (1980) Age changes in bone mineralization, cortical thickness, and haversian canal area. Calcif Tissue Int, 31: 5-11. 